\title{
ANALISIS PENERIMAAN PEMBAYARAN LISTRIK PASKA BAYAR DAN PRABAYAR TERHADAP PENDAPATAN PT. PLN di NGAWI.
}

\author{
Nurul Janahti \\ Isharijadi \\ Pendidikan Akuntansi IKIP PGRI Madiun
}

\begin{abstract}
The purpose of this study was to determine how the effectiveness of the receipt of payment postpaid and prepaid electricity to earnings PT. PLN in Ngawi. Type of research by the author is a qualitative descriptive study, the type of data the author was interviewing, observation and data analysis methods are collected, compiled, interpreted, analyzed, thus providing a complete description. Based on the research conducted, the authors conclude that the effectiveness tinggkat between postpaid and prepaid electricity in 2011 was still effective prepaid electricity, but for greater earnings power postpaid. For postpaid electricity ineffective due each month PT. PLN UPJ Ngawi suffered losses from delinquent customers and for prepaid electricity more effectively but the amount of prepaid electricity customers still small. Contributions related electric revenue postpaid and prepaid electricity PT.PLN UPJ Ngawi more profitable prepaid electricity, because of the effectiveness of the payment easier to use a prepaid system, it is also proportional to the increased number of prepaid subscribers in 2011.
\end{abstract}

Keyword: Receipt of Paymen, Electric Postpaid, Prepaid Electricity, Revenue PT.PTN UPJ Ngawi

\begin{abstract}
ABSTRAK
Tujuan penelitian ini adalah untuk mengetahui bagaimana keefektifan dari penerimaan pembayaran listrik paska bayar dan prabayar terhadap pendapatan PT. PLN di Ngawi. Jenis penelitian yang dilakukan penulis adalah penelitian deskriptif kualitatif, jenis data yang dilakukan penulis adalah wawancara, observasi dan metode analisis data dikumpulkan, disusun, diinterprestasikan, dianalisis, sehingga memberikan keterangan yang lengkap. Berdasarkan hasil penelitian yang dilakukan, penulis dapat menyimpulkan bahwa tinggkat efektivitas antara listrik paska bayar dan prabayar pada tahun 2011 masih efektif listrik prabayar, akan tetapi untuk pendapatannya lebih besar listrik paska bayar. Untuk listrik paska bayar tidak efektif karena setiap bulannya PT. PLN UPJ Ngawi mengalami kerugian dari tunggakan pelanggan dan untuk listrik prabayar lebih efektif tetapi jumlah pelanggan listrik prabayar masih sedikit. Kontribusi terkait pendapatan listrik paska bayar dan listrik prabayar PT.PLN UPJ Ngawi lebih menguntungkan listrik prabayar, karena dilihat dari efektivitas pembayaran lebih mudah menggunakan sistem prabayar, hal ini juga sebanding dengan peningkatan jumlah pelanggan prabayar pada tahun 2011.
\end{abstract}

Kata Kunci : Penerimaan Pembayaran, Listrik paska bayar, listrik prabayar, Pendapatan PT. PLN UPJ Ngawi.

\section{PENDAHULUAN}

Listrik sebagai sumber kehidupan masyarakat, mempunyai fungsi sebagai penerangan dan energi dalam mengembangkan segala bentuk usaha dan aktivitas seharihari. Karenanya listrik merupakan suatu energi yang berperan penting, dimana listrik adalah satu-satunya energi yang mampu menjalankan segala bentuk aktivitas 
operasional dalam pengendalian sarana komunikasi, informasi di kantor, perusahaan, pendidikan maupun kegiatan rumah tangga.

Di zaman modern ini, listrik merupakan kebutuhan pokok bagi kehidupan manusia sehingga menyebabkan manusia beranggapan bahwa zaman modern ini adalah zaman serba listrik. Ketergantungan manusia akan listrik terjadi karena energi tersebut sangat fleksibel.

Selama ini pelanggan PLN mendapat layanan listrik paska bayar, yaitu pelanggan menggunakan energi listik dulu dan membayar belakangan, pada bulan berikutnya. Setiap bulan PLN harus mencatat meter, menghitung dan menerbitkan rekening yang harus dibayar pelanggan, melakukan penagihan kepada pelaggan yang terlambat atau tidak membayar, dan memutus aliran listrik jika konsumen terlambat atau tidak membayar rekening listrik setelah waktu tertentu. Listrik paska bayar dikatakan efektif jika pelanggan tepat waktu membayar dalam setiap bulannya. PLN (2010:2)

Mekanisme tersebut diatas tidak dilaksanakan pada sistem prabayar. Pada sistem prabayar, pelanggan harus mengeluarkan uang atau membayar dulu energi listrik yang akan dikonsumsinya. Besar energi listrik telah dibeli oleh Pelanggan dimasukkan ke dalam Meter Prabayar yang terpasang di lokasi pelanggan melalui sistem token atau strom. (PLN, 2010:2) Eldon S. Hendriksen, 2000 (terjemahan Herman Wibowo,2000:374) berpendapat bahwa "pendapatan (revenue) dapat diidentifikasikan secara umum sebagai hasil dari suatu perusahaan. Hal itu biasanya diukur dalam satuan harga pertukaran yang berlaku. Tujuan diciptakan produk listrik prabayar yaitu untuk meningkatkan kepuasan pelanggan, sehinga nantinya dapat berpengaruh terhadap pendapatan PT. PLN Ngawi.

Meter prabayar menyediakan informasi jumlah energi listrik ( $\mathrm{kWh}$ ) yang masih bisa dikonsumsi. Listrik prabayar dikatakan efektif karena persediaan $\mathrm{kWh}$ tersebut bisa ditambah berapa saja dan kapan saja sesuai kebutuhan dan keinginan pelanggan. Dengan demikian pelanggan bisa lebih mudah mengoptimalkan konsumsi listrik dengan mengatur sendiri jadual dan jumlah pembelian listrik, kendali penggunaan listrik sepenuhnya ada pada diri pelanggan. Kekhawatiran tagihan listrik membengkak tidak perlu lagi terjadi. Baik yang disebabkan oleh penggunaan listrik yang tidak terkontrol maupun terjadinya kesalahan baca meteran. Dengan membeli listrik di awal, hal-hal yang tidak diinginkan tersebut tidak perlu lagi terjadi. (PLN, 2010)

Menurut Muhamad Mahsun (2006:183) Efektivitas merupakan ukuran berhasil tidaknya suatu organisasi mencapai tujuannya, apabila suatu organisasi berhasil mencapai tujuannya maka organisasi tersebut dikatakan telah berjalan dengan efektif. Dari tahun 2009 listrik prabayar sudah ada, tetapi untuk daerah Ngawi sendiri baru tahun 2011 di sosialisasikan ke masyarakat dan pada bulan Maret masyarakat baru mulai berpindah ke prabayar. Sampai saat ini sudah 8.174 dari 133.581 masyarakat Ngawi beralih ke pra bayar. Ditargetkkan nantinya semua pelanggan beralih ke prabayar.

Abdul Salam (2008) listrik prabayar menunjukkan perubahan yang terjadi pada perilaku pelanggan dalam memanfaatkan energi listrik secara lebih hemat. Ditinjau dari Aspek Sistem dan Teknologi, pelaksanaan sistem layanan pra bayar dapat menghindari kesalahan yang ditimbulkan akibat pembacaan meter, input data maupun proses pemakaian rekening, yang secara ekonomi mempunyai nilai bagi perusahaan maupun bagi pelanggan. Ditinjau dari aspek pelayanan, pelaksanaan sistem layanan prabayar 
menunjukkan bahwa proses bisnis yang dijalankan pada sistem ini dapat mempersingkat umur piutang.

Untuk listrik prabayar sendiri cara pembayarannya lebih efektif karena pelanggan tinggal membeli stromm / voucher yang berisikan 20 digit angka, kemudian angka tersebut diisikan kedalam meter prabayar, listrik sudah bisa digunakan. Akan tetapi orang yang masih awam beranggapan listrik paska bayar lebih mudah dari prabayar dengan alasan listrik prabayar sulit karena masih harus memasukkan nomer voucher tetapi jika paska bayar tinggal membayar di kantor PLN. Listrik prabayar ataupun paska bayar sebenarnya sama saja tergantung dari kita masing-masing bagaimana cara pemakaian sehemat, seminimal dan seefektif mungkin.

Masyarakat atau pelanggan baru mengeluhkan listrik prabayar, listrik tiba-tiba mati karena kehabisan pulsa. Rupanya, mereka tidak tahu bahwa listrik prabayar dilengkapi alarm khusus sebagai peringatan pulsa habis. Karena tidak paham, pelanggan mengabaikan meski alarm berbunyi. Akibatnya, listrik mati karena pulsa habis. Masalah lain yang sering dikeluhkan adalah ketersediaan loket pembelian voucher isi ulang. Dengan adanya produk baru (Listrik prabayar) diharapkan dapat memenuhi kebutuhan Masyarakat luas dan bagi PLN khususnya dapat meningkatkan pendapatan.

\section{KAJIAN TEORI Efektivitas}

Efektivitas menunjukan keberhasilan dari segi tercapai tidaknya sasaran yang telah ditetapkan. Jika hasil kegiatan semakin mendekati sasaran, berarti makin tinggi efektivitasnya.

Menurut Deddi Nordiawan dan Ayuningtyas Hertianti (2010:161) efektivitas menunjukkan "kesuksesan atau kegagalan dalam pencapaian tujuan sebuah kegiatan atau kebijakan dimana ukuran efektivitas merupakan refleksi input. Efektivitas terkait dengan hubungan antara hasil yang diharapkan dengan hasil yang sesungguhnya dicapai. Efektivitas merupakan hubungan antara output dengan tujuan. Semakin besar kontribusi output terhadap pencapaian tujuan, maka semakin efektif organisasi, program atau kegiatan".. Efektivitas mengarah pada pendapatan, suatu tambahan pengahasilan dari suatu aktifitas perusahaan dan dapat menabah kekayaan suatu perusahaan tersebut.

Efektivitas tidak menyatakan tentang berapa besar biaya yang telah dikeluarkan untuk mencapai tujuan, tetapi efektivitas hanya melihat apakah suatu pekerjaan atau kegiatan telah mencapai tujuan yang di tetapkan.

Menurut Hendriksen Eldon s. dan Michael f. Van breda (2000:374) "pendapatan (revenue) dapat diidentifikasikan secara umum sebagai hasil dari suatu perusahaan. Hal itu biasanya diukur dalam satuan harga pertukaran yang berlaku. Pendapatan harus diakui setelah kejadian penting atau setelah proses penjualan pada dasarnya telah diselesaikan".

Pendapatan adalah arus masuk bruto dari manfaat-manfaat ekonomi yang timbul dari aktifitas-aktifitas normal perusahaan selama suatu periode bila arus masuk tersebut mengakibatkan kenaikan ekuitas, yang tidak berasal dari kontribusi penanaman modal," Itu berarti pendapatan merupakan penghasilan yang timbul dari aktivitas perusahaan yang dikenal dengan sebutan yang berbeda-beda seperti penjualan, penghasilan jasa, bunga dan royalti. (Akuntansi Keuangan (SAK) 2009 :23.2).

Efektivitas pendapatan merupakan suatu tingkat tercapainya keberhasilan atau rencana kerja perusahaan dalam mengelola pendapatan sesuai dengan target atau tujuan yang telah ditetapkan. Dimana komponen untuk menilai suatu pendapatan efektif yaitu dari anggaran dan realisasi pendapatan pada perusahaan. 


\section{Listrik paska bayar}

Listrik paska bayar (Reguler) adalah sistem pelayanan penjualan tenaga listrik dimana pelanggan membayar listrik setelah penggunaan (PLN,2010:6).

Kelemahan penggunaan listrik paska bayar (PLN, 2010:6) :

a. Jika terlambat membayar listrik, maka aliran listrik akan diputus

b. Tidak bisa mengontrol pemakaian energi listrik

c. Jika pagar rumah dikunci maka petugas baca meter tidak membaca pemakaian energi listrik dirumah.

\section{Listrik prabayar}

Listrik prabayar adalah cara baru bagi pelanggan untuk mengelola dan mengendalikan sendiri pemakaian listrik sesuai kebutuhan dan keinginan pelanggan.(PLN, 2010:5)

1. Keuntungan listrik prabayar bagi pelanggan. (PLN, 2010:5):

a. Pelanggan bisa membeli strom prabayar di payment point, teller Bank, sms Banking dan ATM dengan jaringan yang luas.

b. Pelanggan tidak perlu repot membukakan pintu rumah karena tidak akan didatangi petugas pencatat meter

c. Tidak ada istilah menunggak, sehingga tidak akan didatangi petugas penagihan

d. Tidak ada kesalahan pencatatan meter

e. Privasi pelanggan tidak terganggu

2. Manfaat yang diperoleh PT. PLN pada sistem prabayar (PLN, 2010:5):

a. Mempercepat penerimaan arus kas

b. Mengurangi keluhan khususnya yang terkait dengan kesalahan pencatatan meter

c. Siklus tagihan yang lebih sederhana dan murah

d. Mengurangi kecurangan/kesalahan baca meter

e. Meniadakan tunggakan

f. Menekan biaya operasional akibat tidak adanya kegiatan catat meter dan pemutusan.

\section{METODOLOGI PENELITIAN \\ Pendekatan dan Jenis Penelitian}

Pendekatan penalitian ini dilakukan dengan menggunakan pendekatan kualitatif. Penelitian kualitatif lebih menekankan analisisnya pada proses penyimpulan deduktif dan induktif serta pada analisis terhadap dinamika hubungan antar fenomena yang diamati, dengan menggunakan logika ilmiah (Wirarta, 2006). Peneliti mendiskripsikan, menguraikan, menggambarkan, dan menganalisis keefektifan pembayaran listrik paska bayar dan prabayar terhadap pendapatan PT PLN UPJ NGAWI. Peneliti menggunakan data primer dari laporan keuangan perusahaan bulan Februari sampai Desember tahun 2011.

\section{Teknik Pengumpulan Data}

Teknik pengumpulan data yang digunakan dalam penelitian ini adalah wawancara dan dokumentasi. Wawancara adalah proses memperoleh keterangan untuk tujuan penelitian dengan cara tanya jawab, sambil bertatap muka antara penanya atau pewancara dengan sipenjawab atau responden dengan menggunakan alat yang dinamakan interview guide (Nasir, 2009). Pelaksanaan metode ini digunakan untuk mendapatkan data yang dibutuhkan dalam penelitian. Analisis dokumen menjadi penting manakala kita hendak meneliti bagaimana sebuah dokumen dipakai atau jika dokumen tersebut merupakan perwujudan dari elemen penting yang relevan dengan 
fenomena yang diteliti (sujoko efferin, dkk 2008). Analisis dokumen dimaksudkan peneliti untuk mengakuratkan data yang diperoleh sehingga data benar-benar valid.

\section{Teknik Keabsahan Data}

Dalam setiap penelitian, harus diusahakan kemantapan dan kebenarannya, sehingga dalam setiap penelitian harus bisa memilih dan menentukan cara-cara yang tepat untuk bisa mengembangkan validitas data yang diperolehnya. Cara pengumpulan data dengan beragam tekniknya harus benarbenar sesuai dan tepat untuk menggali data yang benar-benar diperlukan dalam penelitian. Ketepatan data tersebut tidak hanya tergantung dari ketepatan memilih data dan teknik pengumpulannya, tetapi juga diperlukan teknik pengembangan validitas datanya. Penelitian kualitatif terdapat beberapa cara yang bisa dipilih untuk mengembangkan validitas data penelitian. Cara-cara tersebut antara lain berupa teknik tringulasi sumber. Menurut Patton dalam Maleong (2011) tringulasi dengan sumber berarti membandingkan dan mengecek balik derajat kepercayaan suatu informasi yang diperoleh melalui waktu dan alat yang berbeda dalam penelitian kualitatif. Hal ini dicapai dengan jalan membandingkan hasil pengamatan dengan suatu hasil wawancara pada bagian pemasaran PT. PLN Ngawi serta membandingkan hasil wawancara dengan dokumenm arsip, laporan yang berkaitan.

\section{Teknik Analisis Data}

Penulis melakukan analisis data untuk mengolah data yang terkumpul sehingga menghasilkan suatu kesimpulan yang dapat dipertanggungjawabkanm meliputi:

1. Analisis sistem penerimaan kas

2. Analisis efektivitas pendapatan listrik paska bayar dan pendapatan listrik prabayar

3. Menginterprestasikan hasil analisis data.

\section{ANALISIS HASIL DAN PEMBAHASAN}

Perusahaan penyedia layanan listrik sering terjadi permasalahan dengan pelanggan diantaranya yaitu pembekakan tunggakan dari pelanggan. Oleh karena itu diperlukan sistem dan kebijakan dalam memberikan layanan yang optimal. Layanan yang disediakan berkaitan dengan sistem pembayaran listrik prabayar dan paska bayar (regular). Dimana perlu diketahui seberapa besar efektifitas dari adanya sistem tersebut.

Permasalahan yang ada pada PT PLN UPJ Ngawi adalah penunggakkan pembayaran dengan adanya pembayaran listrik paska bayar. Dimana total dari tunggakan tersebut sebesar Rp. 343.606.779,. dengan besar kerugian ini perlu dikaji seberapa efektifkah sistem regular ini dengan adanya penawaran sistem yang baru.

1. Pelaksanaan pembayaran dengan paska bayar.

Sistem paska bayar sudah digunakan sejak bertahun-tahun dan jelas bahwa sistem ini dirasa sangat efektif untuk saat ini. Ini terbukti dari total pertumbuhan pengguna sistem kurang lebih sebanyak 133.581 pelanggan.

Dengan pelanggan sebanyak ini dapat di artikan bahwa penggunaan sistem ini sudah sesuai dengan keinginan pelanggan. Pengecekan dilakukan oleh petugas dari PLN setempat dan pelanggan hanya akan membayar sesuai dengan jumlah dalam meteran listrik yang di pakai selama satu bulan pemakaian.

2. Pelaksanaan pembayaran dengan prabayar

Prosedur sistem prabayar sebenarnya juga efektif dengan tingkat pemakaian naik kurang lebih 8174 pelanggan dalam kurun waktu 1 tahun dari berlakunya sistem ini.

Dimana pelanggan dapat mengatur kebutuhan akan daya listrik dan penggunaannya sekaligus tidak adanya pemborosan. Pihak PLN juga memberikan layanan beda apabila pelanggan melakukan hajatan maka di berikan meteran pembanding agar pengeluaran konsumen sesuai dengan kebutuhan. 


\section{HASIL}

Analisis pembayaran listrik paska bayar dan prabayar kaitannya dengan pembahasan penelitian efektifitas penggunaan sistem ini yang diperoleh dari PLN UPJ Ngawi pada tabel berikut :

\section{Penjelasan}

1. Pendapatan listrik paska bayar antara antara budget dan realisasinya lebih besar realisasinya dan untuk listrik prabayar antara budget dan realisasinya lebih besar realisasi.

2. Antara listrik paska bayar dan prabayar dapat diketahui bahwa tingkat pendapatan listrik paska bayar lebih besar dibandingkan listrik prabayar yaitu pendapatan untuk listrik paska bayar sebesar Rp.83.330.225.501 dan listrik prabayar sebesar Rp.2.664.503.575.

3. Analaisis pada sistem paska bayar ditemukan fakta bahwa PLN UPJ Ngawi mendapat tunggakan yang tidak dapat diperkirakan karena listrik akan selalu tersambung apabila tidak ada pemutusan sehingga dapat dipastikan kerugian akan muncul, total kerugian rata-rata pertahun sebesar Rp.343.606.779.

4. Dalam penggunaan listrik paska bayar pelanggan merasakan kepuasan tersendiri, karena tanpa pembayaran awal sudah dapat menikmati fasilitas listrik yang disediakan oleh PLN UPJ Ngawi. Dengan ini jelas keuntungan akan diperoleh oleh pelanggan.

5. Analisis sistem pembayaran dengan prabayar memiliki peningkatan yang positif dari sejak pertama dikenalkan dan PLN UPJ Ngawi dapat meminimalkan tingkat kerugian dari pemberian fasilitas listrik. Pada sistem ini tingkat efektifitasnya dapat dirasakan pada kedua belah pihak, baik pada pihak penyedia layanan sekaligus pengguna layanan tersebut.

6. Tingkat pengguna sistem prabayar sampai dengan 31 desember 2011 kurang lebih 8.174 dengan ini diharapkan setiap tahunnya pelanggan listrik prabayar terus meningkat.

\section{Solusi}

Untuk meningkatkan efektivitas sistem prabayar PT. PLN UPJ Ngawi perlu adanya seminar atau lokakarya untuk mensosialisasikan program listrik prabayar kepada masyarakat atau pemuka daerah sehingga mereka mengetahui mengenai kelebihan dan kekurangan program listrik prabayar.

Dengan adanya seminar atau lokakarya akan muncul kerjasama yang baik antara perusahaan dengan masyarakat atau pelanggan, sehingga dapat meningkatkan efektivitas pendapatan PT. PLN UPJ Ngawi. Penggunaan listrik dan sistem pembayarannya juga akan semakin membaik, tunggakan-tunggakan tidak akan muncul lagi di PT. PLN UPJ Ngawi

\section{KESIMPULAN DAN SARAN}

Berdasarkan proses analisis, wawancara, observasi dan berbagai dokumentasi, maka dari penelitian "Analisis Efektivitas Penerimaan Pembayaran Listrik Paska Bayar dan Listrik Prabayar Terhadap Pendapatan PT PLN UPJ Ngawi” penulis dapat menarik simpulan sebagai berikut :

1. Berdasarkan analisis tingkat efektifitas antara listrik paska bayar dan prabayar untuk tahun 2011 lebih efektif listrik prabayar. Akan tetapi jumlah pendapatannya 
lebih besar paska bayar hal ini dikarenakan pelanggan atau pengguna listrik paska bayar lebih besar dari pada prabayar.

2. Listrik paska bayar tidak efektif dikarenakan setiap bulannya PT. PLN UPJ Ngawi mengalami kerugian atau tunggakan, sedanggan listrik prabayar lebih efektif tetapi jumlah pelanggan listrik prabayar masih sedikit dibandingkan pelanggan listrik paska bayar.

3. Kontribusi terkait pendapatan listrik paska bayar dan prabayar PT. PLN UPJ Ngawi lebih menguntungkan listrik prabayar dari pada listrik paska bayar, karena dilihat dari efektivitas pembayaran lebih mudah menggunakan sistem prabayar, hal ini juga sebanding dengan peningkatan jumlah pelanggan prabayar pada tahun 2011.

4. Berdasarkan rekapitulasi penjualan listrik paska bayar dan prabayar diketahui prosentase pendapatan listrik prabayar lebih besar, yaitu prosentase pendapatan paska bayar 70,16\% dan listrik prabayar 74,73\%.

Dari kesimpulan tersebut, penulis memberikan saran yang mungkin dapat diterapkan pada PT PLN UPJ Ngawi guna meningkatkan pendapatan dari adanya dua sistem pembayaran dari penggunaan daya listrik sebagai berikut :

1. Pada proses paska bayar PT PLN UPJ Ngawi memberikan layanan yang dekat dengan pengguna dengan melakukan pembayaran listrik keliling dengan bekerjasama dengan instansi atau pihak yang di berdayakan oleh PT PLN UPJ Ngawi sehingga dapat meminimalisir terjadinya tunggakan pada pelanggan.

2. Perlu adanya penyuluhan berkaitan dengan sistem penbayaran listrik prabayar pada pelanggan tentang jenis layanan yang ditawarkan dan kemudahan-kemudahan yang dimiliki listrik prabayar untuk pelanggan misalnya penyuluhan yang berkaitan dengan proses untuk regristasi kedalam listrik prabayar.

3. PT. PLN UPJ Ngawi memberikan sanksi pada pelanggan paska bayar yang menunggak pembayarannya, yaitu mengalihkan pelanggan listrik paska bayar ke listrik prabayar dan dengan dikenakan membayar uang denda atas tunggakan

\section{DAFTAR PUSTAKA}

Deddi Nordiawan, Ayuningtyas Hertianti. 2010. Akutansi Sektor Publik. Jakarta:Salemba Empat.

Eldon S. Hendriksen, Michael F. Van Breda. 2002. Teori Akutansi. Batam Centre:Interaksara.

Ikatan Akutansi Indonesia. 2009. Standart Akutansi Keuangan. Jakarta:Salemba Empat

Lexy J. Moleong. 2011. Metedeologi Penelitian Kualitatif. Bandung:PT. Remaja Rosdakarya.

Nasir, M.2009. Metode Pemelitian.Bogor:Ghalia Indonesia.

Sujoko Efferin Dkk. 2008. Metode Penelitian Akutansi. Yogyakarta:Graha Ilmu.

Standart prosedur pelayanan prabayar. 2010. prosedur pelayanan listrik prabayar. Jakarta: PT.PLN (persero).

Wirartha,I Made.2006.Metedeologi Penelitian Sosial Ekonomi.Yogyakarta:Andi 